\title{
DO HIGHER CIGARETTE PRICES ENCOURAGE YOUTH TO USE MARIJUANA?
}

\author{
Frank J. Chaloupka \\ Rosalie Liccardo Pacula \\ Matthew C. Farrelly \\ Lloyd D. Johnston \\ Patrick M. O'Malley \\ Jeremy W. Bray \\ Working Paper 6939 \\ http://www.nber.org/papers/w6939
NATIONAL BUREAU OF ECONOMIC RESEARCH
1050 Massachusetts Avenue
Cambridge, MA 02138
February 1999

The views expressed here are those of the author and do not reflect those of the National Bureau of Economic Research.

( 1999 by Frank J. Chaloupka, Rosalie Liccardo Pacula, Matthew C. Farrelly, Lloyd D. Johnston, Patrick M. O'Malley, and Jeremy W. Bray. All rights reserved. Short sections of text, not to exceed two paragraphs, may be quoted without explicit permission provided that full credit, including ${ }^{\circledR}$ notice, is given to the source. 
Do Higher Cigarette Prices Encourage

Youth to Use Marijuana?

Frank J. Chaloupka, Rosalie Liccardo Pacula, Matthew C. Farrelly, Lloyd D. Johnston,

Patrick M. O'Malley, and Jeremy W. Bray

NBER Working Paper No. 6939

February 1999

JEL No. I18

\section{ABSTRACT}

Every major national tobacco legislation proposed in the past two years has called for significant increases in the price of cigarettes as a way to discourage youths from smoking. One argument used to oppose these bills is that increases in the price of cigarettes would cause youths to substitute marijuana for cigarettes. Although it has long been believed that cigarettes are a "gateway drug," no economic research has been done to determine whether cigarettes and marijuana are economic complements or substitutes.

This paper begins to fill the void in the current research by examining the contemporaneous relationship between the demands for cigarettes and marijuana among a nationally representative sample of $8^{\text {th }}, 10^{\text {th }}$ and $12^{\text {th }}$ graders from the $1992-1994$ Monitoring the Future Project. Two part models are used to estimate reduced form demand equations. Examination of the cross-price effects clearly shows that higher cigarette prices will not increase marijuana use among youths. In addition to reducing youth smoking, we find that higher cigarette prices significantly reduce the average level of marijuana used by current users. Cigarette prices also have a negative effect on the probability of using marijuana, but these findings are not significant at conventional levels.

Frank J. Chaloupka

Department of Economics

University of Illinois at Chicago

601 South Morgan Street

Chicago, IL 60607

and NBER

fjc@uic.edu

Matthew C. Farrelly

Center for Economic Research

Research Triangle Institute

3040 Cornwallis Rd.

Research Triangle Park, NC 27709

mcf@rti.org

Jeremy W. Bray

Center for Economic Research

Research Triangle Institute

3040 Cornwallis Rd.

Research Triangle Park, NC 27709

bray@rti.org
Rosalie Liccardo Pacula

RAND

1700 Main St.

P.O. Box 2137

Santa Monica, CA 90407

and NBER

pacula@rand.org

Lloyd D. Johnston

Institute for Social Research

University of Michigan

426 Thompson St.

Ann Arbor, MI 48104-2321

llyodj@isr.umich.edu

Patrick M. O'Malley

Institute for Social Research

University of Michigan

426 Thompson St.

Ann Arbor, MI 48104-2321

POmalley@isr.umich.edu 


\section{Introduction}

Every major proposal for national tobacco legislation introduced during the past two years called for significant increases in the price of cigarettes as a way to discourage teens from smoking. The original June 20, 1997 agreement between the tobacco industry and states' Attorneys General called for the costs of the settlement to be passed on to smokers in the form of higher prices, which would have increased cigarette prices by 62-cents per pack, or more (Federal Trade Commission, 1997). Senator McCain's proposal included a $\$ 1.10$ increase to be phased in over five years while Senator Kennedy proposed a $\$ 1.50$ increase phased in more rapidly, with both calling for adjustments to keep pace with inflation. Larger increases of up to $\$ 2.00$ per pack were proposed by various public health groups.

A number of issues concerning the effectiveness and appropriateness of using large price increases to discourage youth tobacco use were raised in the debate over these proposals and ultimately led to their defeat. In addition, opponents of the price hikes suggested that even if they did succeed in discouraging youth from smoking, large cigarette price increases would lead youths to substitute towards other substances, particularly marijuana. While there is little, if any, empirical evidence that this type of substitution would occur, there is considerable evidence to suggest the opposite could result. That is, in addition to reducing youth smoking, higher cigarette prices could reduce other substance use among youth. For example, cigarettes have long been thought to be a "gateway drug," in that early experimentation with cigarettes encourages youths to try marijuana and other illicit substances (i.e. Kandel, 1975; Ellickson, Hays and Bell, 1992; Kandel and Yamaguchi 1993). Other research has concluded that cigarette smoking is a significant predictor of both the probability and frequency of other drug use (i.e. Clayton and Ritter, 1985; U.S. Department of Health and Human Services, 1988; Henningfield, 
Clayton, and Pollin, 1990). For example, citing data from the 1985 National Household Survey on Drug Abuse, the 1988 Surgeon General Report states that teens who smoke are three times more likely to use alcohol, eight times more likely to use marijuana, and twenty-two times more likely to use cocaine (USDHHS, 1988). Using the same data, Henningfield and his colleagues found that young daily cigarette smokers were 114 times more likely to have used marijuana heavily (11 times or more in the past 30 days). This suggests that cigarettes and other substances are complements for one another and that higher cigarette prices, by discouraging smoking among youth, could also lead to significant reductions in youth and adult drinking and illicit drug use.

The fact that policy makers are considering the ripple effects of policies targeting one substance on the use of other substances is a major leap forward in the area of substance control policy. However, the economic research exploring the relationship between the demands for different drugs that is needed to inform these discussions is sorely lacking. This paper begins to address the gap in existing research by examining the relationship between the contemporaneous demands for cigarettes and marijuana in a nationally representative sample of eighth, tenth, and twelfth grade students from the 1992 through 1994 Monitoring the Future Study. In particular, this paper examines the impact of cigarette prices, tobacco control policies, marijuana policies, and alcohol prices on youth cigarette smoking and marijuana use. Estimates generated from two part models indicate that higher cigarette prices, in addition to reducing youth smoking, will significantly reduce the average level of marijuana used by current users. They further suggest that higher cigarette prices will reduce the likelihood that youths use marijuana, although these findings are not significant at conventional levels. Elasticities calculated from short and long form specifications suggest that a $10 \%$ increase in the price of cigarettes would reduce the 
probability of using marijuana between 3.4\%-7.3\% and decrease the average level of marijuana use by regular users between 3.6\%-8.4\%.

\section{Literature Review}

In part because of the lack of good data on the prices for and use of illicit drugs, economists have contributed little to the debate over the relationship between cigarette smoking and other drug use. To date, only three studies have analyzed the economic relationship between the demands for cigarettes and marijuana. In the only published analysis, Pacula (1998a) used data from the 1984 National Longitudinal Survey of Youth (NLSY) to estimate the current demand for alcohol and marijuana for a sample of young adults between the ages 19 and 26 . Although she did not estimate a demand equation for cigarettes directly, she included the current state cigarette tax as an additional regressor in her models in order to identify whether a significant cross-price effect exists. Her analyses also included state and federal beer taxes, the minimum legal purchase age for alcoholic beverages, an indicator for decriminalized states, and the crime per officer ratio, which was her proxy for the monetary price of marijuana. Pacula found that cigarette taxes had no significant effect on the current likelihood of using marijuana or the conditional quantity consumed. She reached the opposite conclusion, however, in later work that focused on the intertemporal relationship between alcohol and marijuana using data from the 1983 and 1984 NLSY (Pacula, 1998b). In this analysis, which controlled for persistence in the consumption of both drugs over time, Pacula found that cigarette prices have a negative and statistically significant effect on the probability of using marijuana, suggesting that cigarettes and marijuana are economic complements for young adults. She also found that higher past prices of cigarettes have a negative and significant effect on the probability of using marijuana, supporting 
an intertemporal complementary relationship between the two substances. Although much of the inconsistency in findings across these two studies can be attributed to differences in controls and model specification, this variation in findings is still unsettling. ${ }^{1}$

In a working paper using more recent data, Farrelly, et al (1998) estimated the decision to use alcohol, tobacco and marijuana for a nationally representative sample of youths (ages 12 to 20) and young adults (ages 21 to 30) from the 1990-1996 National Household Surveys on Drug Abuse. Measures of the real price of beer, the real price of cigarettes, marijuana possession arrests over total arrests and cannabis eradication (used as a proxy for the monetary price of marijuana) were included in probit specifications of the probability of using each substance, making it possible to analyze cross-price effects. They further controlled for unobserved timeinvariant state-specific effects that may be correlated with policy measures by including a series of dummy variables for each state. Their results indicated that tobacco, marijuana and alcohol are economic complements for youth. Higher cigarette prices decreased the probability of using marijuana, as did higher beer prices. The calculated cross-price participation elasticities of cigarette prices and alcohol prices on marijuana use were -0.49 and -1.05 , respectively. Crossprice effects for adults, however, were insignificant although the signs indicated a weak complementary relationship.

This paper builds on this limited econometric research by further investigating the relationship between the demands for tobacco and marijuana among youths. Unlike previous studies, this study examines the prevalence and average level of use of cigarettes and marijuana among a nationally representative sample of eighth, tenth and twelfth graders. This age

\footnotetext{
${ }^{1}$ In the contemporaneous analysis (Pacula, 1998a), the natural logarithm of the state tax was employed, which significantly reduced the variation in this measure of price and reduced its expected predictive power. The later analysis (Pacula, 1998b) entered the state average price of cigarettes, inclusive of taxes, linearly into the model.
} 
group is particularly important for examining substance use behavior since most youths initiate use during these years. Findings from this study can help inform the current debate over the potential unintended consequences of raising cigarette prices.

\section{Data and Methods}

The data on youth cigarette smoking and marijuana use employed in this study come from the 1992 through 1994 Monitoring the Future Surveys of eighth, tenth and twelfth grade students. The Monitoring the Future Survey is an annual school-based survey focused on youth perceptions of, attitudes towards, and use of alcohol, tobacco, and other drugs. The survey was developed and is conducted by the Institute for Social Research (ISR) at the University of Michigan. Each year since 1975, ISR has surveyed a nationally representative sample of high school seniors; beginning in 1991, comparable surveys of eighth and tenth grade students have been conducted. Detailed information on the survey design and sampling methods is available in Johnston, et al. (1998). Given the focus of the surveys on youth substance use, great care is taken to ensure that the youths' responses are reliable and valid. See Johnston and O'Malley (1985) for a detailed discussion of validity of these data.

Two measures of youth cigarette smoking are constructed from the survey data. First, a dichotomous indicator of smoking participation is created from the answer to the question: "How frequently have you smoked cigarettes during the past 30 days?" Anyone reporting a positive amount is defined as a current smoker while those reporting having not smoked at all in the past thirty days are considered nonsmokers. Second, a quasi-continuous measure of average daily cigarette consumption is constructed by assigning the median value of the categorical responses provided to that same question. The possible responses (and their assigned values) include: less 
than one cigarette per day (0.5); one to five cigarettes per day (3); about one-half pack per day (10); about one pack per day (20); about one and one-half packs per day (30); and two packs or more per day (45).

Similar measures of marijuana use are constructed based on the responses to the question: "On how many occasions (if any) have you used marijuana (grass, pot) or hashish (hash, hash oil) during the last 30 days?" 2 A dichotomous indicator of current marijuana use is set equal to one for youth reporting one or more occasions and zero otherwise. A quasi-continuous measure reflecting the frequency of use in the past month is constructed by assigning midpoint values to the categorical responses as follows: 1-2 occasions (1.5), 3-5 occasion (4), 6-9 occasion (7.5), 10-19 occasions (15), 20-39 occasions (30), and 40 or more (40). While neither of these quasicontinuous measures is ideal for capturing total amount consumed, they are helpful in gauging the impact of price and public policies on average daily cigarette consumption and the frequency of marijuana use among teens.

A simple cross-tabulation of current cigarette and marijuana users obtained from the 1992, 1993 and 1994 surveys is reported in Table One. Less than one-quarter of the respondents report using either of these substances in the past thirty days, with $22.7 \%$ reporting cigarette smoking and $10.9 \%$ reporting marijuana use. While the majority of cigarette smokers $(65.8 \%)$ smoked only cigarettes, over seventy percent (71.0\%) of marijuana users also report current cigarette smoking.

In addition to the information on youth smoking and marijuana use, detailed socioeconomic and demographic information is also collected in the surveys. A variety of

\footnotetext{
${ }^{2}$ On Form 1 of the high school senior surveys, this question is broken out so that information pertaining to the use of marijuana can be identified separately from the use of hashish. Forms 2-6, however, ask only the question shown above. To make the responses compatible, the responses to the separate questions in form 1 are combined. If the
} 
potential determinants of youth cigarette smoking and marijuana use are constructed from these data, including: indicators of gender (male or female), race (white, African-American, and other), current grade (eight, tenth or twelfth), marital status (married or engaged versus being single), parental education (less than a high school education, high school graduate, and more than a high school education for mother and father separately), family structure (live alone, live with mother, live with father, both parents present, or other living arrangement), mother's work status while growing up (full-time, part-time, or stay at home), the presence of siblings, living in a urban or rural area, and frequency of participation in religious services (no participation, infrequent participation and frequent participation), and continuous measures of age, average weekly income from all sources (employment, allowances and other), and average number of hours worked weekly. Sample means and standard errors for these variables are provided in Table Two.

Location-specific price and policy measures based on the county and state in which the respondent lives were merged with the survey data. Several measures reflecting the full cost of cigarette smoking by minors were included in the empirical models. The first is the state-level price for a pack of 20 cigarettes, including generics, obtained from the Tobacco Institute's annual Tax Burden on Tobacco. This price represents the weighted-average price of a pack from single packs, cartons and vending machine sales, and includes state-level cigarette taxes. These prices are deflated by the national CPI (1982-1984=1) to obtain the real price of cigarettes. In addition, a variable measuring the largest real price difference for a pack of cigarettes between the youth's state of residence and states within 25 miles of the youth's county of residence is included to capture potential cross-border shopping for cigarettes by young smokers. A larger difference in

respondent reports any use of either marijuana or hashish, he or she is defined as a current user. Frequencies were summed after medians were assigned to each category separately. 
border price is expected to have a positive impact on the probability of using cigarettes as well as the average level of use.

Four additional measures of tobacco control policies were included to capture the general state and local sentiment towards tobacco and youth access to tobacco products. The first is an index of state and local restrictions on smoking in public places and private work sites. This index is constructed as the sum of five variables capturing the fraction of the population in the youth's county of residence that is subject to state or local restrictions in each of the following areas: private worksites, restaurants, retail stores, schools, and other public places. The second is a similarly constructed index of state and local limits on youth access to tobacco. This index is constructed as the sum of two state-level dichotomous variables - one indicating that the minimum legal purchase age for cigarettes is at least 18 years and a second indicating that signs stating the minimum legal age are required at the point of purchase - and three continuous measures - representing the fraction of the population in the youth's county of residence subject to restrictions on vending machine cigarette sales, limits on the distribution of free tobacco samples to youth, and licensure requirements for tobacco retailers. Third, a dummy variable equal to one in states that earmark a portion of the revenues generated by cigarette excise taxes to fund anti-tobacco activities, and zero otherwise is included. Finally, an indicator of smoker protection laws is added. Data on state level policies were obtained from various years of the Coalition on Smoking OR Health's (CSH) annual State Legislated Actions on Tobacco Issues. The primary source of information on local level restrictions was the National Cancer Institute's 1993 Monograph summarizing major local control policies, updated with information from CSH.

To capture the full price of marijuana, a series of alternative measures reflecting the potential legal costs associated with the possession of marijuana are included. The first is a 
dichotomous indicator set equal to one in those states that have decriminalized the possession of small amounts of marijuana, generally less than an ounce. In these states, it is not a felony to possess small quantities of marijuana although it is still a crime. In addition, measures of the median fine and jail time that can be imposed for possession of an ounce of marijuana on the first offense are included. These data were obtained from various years of the Bureau of Justice Statistics' annual Sourcebook on Criminal Justice Statistics, augmented with information from the states' Controlled Substance Acts. In a few states, these measures could be constructed for 1994 only. Rather than lose respondents in these states, the penalties for marijuana possession that were in place in 1994 were assumed to exist in 1992 and 1993 as well and a dummy variable was created to identify the observations affected by this assumption. Sensitivity analyses are conducted to evaluate the impact of this assumption on the estimates.

Because many teens that smoke cigarettes and/or marijuana also drink, a measure of the price of alcohol is included in the cigarette and marijuana demand equations to control for the possible relationships between cigarette, marijuana, and alcohol use. The real state tax on a case of 24 12-ounce cans of beer is used as a proxy the price of alcohol because beer is by far the drink of choice for youths these ages and because these data are available for all states. The beer tax data were obtained from the Brewers Almanac.

After eliminating respondents with missing or inconsistent data, a sample of 109,612 youths remains. ${ }^{3}$ Given the limited nature of the dependent variable, two-part models are employed to estimate youth cigarette and marijuana demand. In the first stage, the likelihood of being a current cigarette or marijuana smoker is estimated using a probit specification. In the second stage, the conditional quantity of cigarettes smoked daily and frequency of marijuana use 
are estimated using log-linear least square methods. Robust standard errors that correct for the clustering of observations at the state level are reported. These are obtained in STATA using the robust cluster option, which is equivalent to requesting Huber-corrected standard errors. This correction accounts for any unobserved correlation in the error terms across individuals within the same state, which could be caused by an unobserved public sentiment toward healthy behaviors for example, but assumes that this correlation is independent of the other regressors in the model.

Two alternative specifications are presented for each equation. The first is a relatively limited specification including the cigarette price and border price difference, beer tax, a decriminalization dummy variable and a variety of socioeconomic and demographic variables constructed from the survey data. The second is a more complete specification that includes the four tobacco-related policy measures and the marijuana possession penalty variables. It is likely that these additional variables are correlated with the unobserved state sentiment toward general use of these substances and are therefore potentially endogenous. By including them as additional regressors, however, we hope to obtain more precise estimates of the effect of cigarette prices and marijuana decriminalization, whose estimates might otherwise be biased upward because of potential correlation with this same unobserved state sentiment. ${ }^{4}$

\footnotetext{
${ }^{3}$ Preliminary analyses including indicators for observations with missing data suggested that these data were missing randomly and that the findings would not be significantly altered by deleting observations with incomplete data.

${ }^{4}$ A more precise way of dealing with the potential correlation between policy variables and the error term would be to estimate a fixed-effect model, which we tried to do. Our relatively short panel does not provide us with sufficient within state variation to estimate the model efficiently however. We therefore present results from the approach described above.
} 


\section{Results}

Table Three reports the marginal effect of a change in each of the independent variables on the average probability that an individual currently smokes cigarettes or uses marijuana. ${ }^{5}$ Column one contains the estimates for cigarette smoking from the relatively limited specification while column two contains those from the expanded specification. Similar estimates for the probability of using marijuana are contained in columns three and four. Table Four reports the estimates from the conditional demand equations in a similar fashion as Table Three.

Cigarette prices are found to have a negative effect in all estimated equations. The estimated coefficients are significant at better than the one-percent significance level in three out of the four cigarette equations. ${ }^{6}$ When additional tobacco control measures are included in the cigarette equations, the marginal effect of the cigarette price falls in the prevalence equation but increases slightly in the conditional demand equation. The implied own-price elasticity for the prevalence of cigarette smoking calculated from the short- and long-form specifications of the model are -0.66 and -0.42 , respectively, while those for the conditional demand equations are -0.62 and -0.71 . These are consistent with previous findings using these data but omit the alcohol and marijuana policy variables (Chaloupka and Grossman, 1996; Chaloupka and Pacula, 1998).

Cigarette prices are also found to have a negative and generally significant effect in the marijuana demand equations. Higher cigarette prices have a statistically significant effect on the average level of marijuana use in both the long and short form specifications. In the prevalence equations, the estimates remain negative but are no longer significant at conventional levels. The

\footnotetext{
${ }^{5}$ Marginal effects for dichotomous variables are calculated as a change in these variables from "0" to "1", not as a one unit change from the mean.
} 
estimate from the long form specification, however, is significant at the $7 \%$ level. The inclusion of additional tobacco control and marijuana policy measures, shown in column four of both tables, leads to a doubling of the estimates, raising some concerns regarding the precision of these estimates. It is clear from these results, however, that higher cigarette taxes will not lead youth to substitute marijuana for cigarettes. The implied cross-price elasticities from the shortand long-form specifications of the prevalence equations are -0.34 and -0.73 , respectively, while those from the conditional demand equations are -0.36 and -0.84 . These estimates suggest that, for teens, cigarettes and marijuana are economic complements for one another. The estimates for the border-price variable generally support this finding of complementarity. Lower border cigarette prices have a positive and, at times, statistically significant effect on the alternative measures of cigarette smoking and marijuana use.

More comprehensive restrictions on cigarette smoking are estimated to have a negative and significant impact on the probability of youth smoking, but appear to have little impact on conditional cigarette demand. In contrast, these restrictions are not found to affect the probability of youth marijuana use, but, surprisingly, are estimated to have a positive and significant impact on the conditional frequency of use. None of the other tobacco-related policy measures is significant in any of the eight equations. These findings suggest that laws limiting youth access to tobacco products, earmark tobacco taxes for anti-smoking media campaigns, and/or protecting smokers do not affect youth smoking or marijuana use. However, no controls for the implementation or enforcement of these policies have been included in the models, which are likely to influence these findings.

\footnotetext{
${ }^{6}$ In general, statements concerning the significance of variables capturing alternative aspects of the own-full price are based on one-tailed significance tests given the law of demand. Those concerning cross-prices are based on twotailed significance tests given the potential substitutability or complementarity of various licit and illicit substances.
} 
With respect to the various proxies for the full price of marijuana, we find that youths living in decriminalized states are significantly more likely to report currently using marijuana and may consume more frequently. The positive effect on the average level of marijuana used by current users is only statistically significant when additional tobacco controls and marijuana policies are included. The magnitudes of the coefficients are also substantially influenced by the inclusion of these policy variables. In contrast, the estimates indicate that youth smoking is unaffected by state decriminalization status.

Youths who currently use marijuana and live in states where higher median fines can be imposed for the possession of up to an ounce of marijuana consume less frequently than those living in states with less severe fines. The comparable measures for jail sentences, however, were not significant in either equation. It should be noted, however, that the indicator for youth in states where the 1994 values of the penalty variables were assumed to apply in earlier years is negative and significant in both of the marijuana use equations in which it is included, suggesting that the findings for the penalty variables could change if more accurate measures were available. Additional runs of the model, which are not presented here, verify that the estimates for other key variables are unaffected by the inclusion or exclusion of the penalty data.

Neither of the marijuana penalty variables or the indicator for states where these data are problematic is significant at conventional levels in the youth cigarette smoking equations. In general, these estimates suggest that while youth marijuana use is reduced by increases in the full price of marijuana, youth cigarette smoking is unaffected. To some extent, these findings support the hypothesis that youth substance use progresses from cigarette smoking to the use of other licit and illicit substances, as described above. That is, increases in the price of cigarettes reduce the likelihood of marijuana use, but increases in the price of marijuana do not 
significantly affect youth smoking. More research using longitudinal data is needed, however, before this can be clearly established.

In contrast, the beer tax is found to have a generally insignificant effect on youth cigarette smoking and marijuana use. The one exception to this is in the expanded version of the conditional frequency of marijuana use equation where it is positive and approaches significance at the $7 \%$ level, consistent with the hypothesis that alcohol and marijuana are economic substitutes for at least young marijuana users. This lack of a consistent finding is consistent with the mixed findings from prior research on the complementarity or substitutability of alcohol and marijuana. DiNardo and Lemieux (1992) and Chaloupka and Laixuthai (1997), for example, conclude that the two were substitutes among youth. In contrast, Farrelly et al (1998), Pacula (1998a, 1998b) and Saffer and Chaloupka (1998) concluded that alcohol and marijuana were complements for youth, young adults, and adults, respectively.

The findings with respect to the socioeconomic and demographic variables are generally consistent with those obtained in other studies. Males are significantly less likely to report currently using cigarettes than females, but among those who do smoke cigarettes young men consume more on average than young women. Young males are also more likely to use marijuana and to consume it more frequently than young females. African American and other non-white youth smoke significantly less than whites, although only African-Americans are significantly less likely to smoke marijuana. Older youths are both more likely to use either substance and, for users, to use more frequently. Teens that work more hours, on average are significantly more likely to smoke cigarettes, but not to use marijuana; among users, however, those working more hours consume more cigarettes per day, and may use marijuana less frequently. Income has a positive and significant impact on both the probability and conditional 
use of both substances. Interestingly, however, the positive effect of income on the probability of using both substances diminishes as income gets larger while the positive effect of income on the conditional use of both substances increases with income.

Youths who attend religious services either frequently or infrequently are significantly less likely to use both substances than youths who do not attend such services and, for users, to consume less. Youths living in nontraditional families are significantly more likely to use either substance and to use more often than those in families where both parents are present. Youth with siblings, however, are less likely to consume either cigarettes or marijuana and, for users, to consume less. Youths with mothers that worked more while they were growing up are significantly more likely to use cigarettes or marijuana than those with mothers who stayed home; among users, however, there are few significant differences. Youth cigarette smoking appears to be inversely related to parental education, while marijuana use appears to have a Ushaped relationship with parental education, although the estimates for marijuana use are not consistently significant. Finally, youths living in the Western states are less likely to smoke cigarettes and smoke significantly less on average than youth living in the South, Midwest or Northeast. They are more likely to use marijuana, however, and use significantly more on average than youths living in other regions of the country.

\section{Conclusions}

Based on the estimates described above, the answer to the question posed in the title of this paper is clearly "No" - higher cigarette prices will not increase youth marijuana use. Instead, these estimates indicate that higher cigarette prices, in addition to reducing youth cigarette smoking, would certainly lower the average frequency of marijuana use among youth users and 
would likely lower the probability of using marijuana. According to these estimates, a tenpercent increase in cigarette price is predicted to lower the prevalence of youth marijuana use between $3.4 \%-7.3 \%$ and decrease the average level of marijuana use by regular users between $3.6 \%-8.4 \%$.

This finding is consistent with the evidence that youth substance use typically progresses from cigarette smoking and other tobacco use to other licit and illicit substance use, implying that policies that would be effective in reducing youth smoking would also lead to reductions in youth drinking, marijuana use, and other illicit drug use. In addition, this finding is consistent with the evidence emerging from the qualitative research conducted by the Centers for Disease Control and Prevention's network of prevention research centers. This research, based on focus groups of young smokers from around the country, suggests that at least some young marijuana users use cigarettes to enhance the high they obtain from smoking marijuana, implying that there are complementarities between youth cigarette and marijuana smoking. Similarly, teens in these groups consistently indicate that there are important qualitative differences between cigarette smoking and marijuana use that would keep them from substituting towards marijuana should cigarette prices increase dramatically (personal communications, George Balch and Robin Mermelstein).

This research clearly takes a very small first step towards evaluating the impact of changes in prices and control policies for one substance on youth use of other substances. Much more research, ideally using appropriate longitudinal data that contain information on the initiation and progression of youth substance use, is needed to adequately address these issues. 


\section{Literature Cited}

Chaloupka FJ, Grossman M. Price, tobacco control policies, and youth smoking. National Bureau of Economic Research Working Paper No. 5740. 1996.

Chaloupka FJ, Laixuthai A. Do youths substitute alcohol and marijuana? Some econometric evidence. Eastern Economic Journal 23(3):253-276, 1997.

Chaloupka FJ, Pacula RL. Limiting youth access to tobacco: The early impact of the Synar Amendment on youth smoking. Presented at the American Public Health Association Annual Meeting, Washington DC. November 1998.

Clayton RR, Ritter C. The epidemiology of alcohol and drug abuse among adolescents. Advances in Alcoholism and Substance Abuse 4 (3-4): 69-97, 1985.

Coalition on Smoking OR Health. State Legislated Actions on Tobacco Issues. Washington, D.C.: Coalition on Smoking OR Health, various years.

Department of Justice. Sourcebook of Criminal Justice Statistics. Washington, D.C.: Bureau of Justice Statistics, various years.

DiNardo, J and Lemieux T. "Alcohol, Marijuana and American Youth: the Unintended Consequences of Government Regulation." National Bureau of Economic Research Working Paper Number 4212, 1992.

Ellickson PL, Hays RD, Bell R. Stepping Through the Drug Use Sequence: Longitudinal Scalogram Analysis of Initiation and Regular Use. Journal of Abnormal Psychology 101(3): 441451, 1992.

Farrelly MC, Bray JW, Zarkin GA, Wendling BW, Pacula RL. The effects of prices and policies on the demand for marijuana: Evidence from the National Household Surveys of Drug Abuse. Working Paper, Research Triangle Institute. 1998.

Federal Trade Commission. Competition and the Financial Impact of the Proposed Tobacco Industry Settlement. Washington, D.C.: Federal Trade Commission, Bureau of Economics, Competition, and Consumer Protection, 1997.

Henningfield JE, Clayton R, Pollin W. Involvement of tobacco in alcoholism and illicit drug use. British Journal of Addiction 85(2): 279-92, 1990.

Johnston LD, O'Malley PM, Bachman JG. National Survey Results on Drug Use From the Monitoring the Future Study, 1975-1994. NIH Publication No. 95-4026. Washington, DC: U.S. Government Printing Office, 1995.

Johnston LD, O'Malley PM (1985). Issues of validity and population coverage in student surveys of drug use. In B.A. Rouse, N.J. Kozel, \& L.G. Richards (Eds.) Self-report methods of 
estimating drug use: Meeting current challenges to validity (NIDA Research Monograph 57). Washington, D.C.: National Institute on Drug Abuse.

Kandel DB. Stages in adolescent involvement in drug use. Science 190: 912-924, 1975.

Kandel DB,Yamaguchi K. From beer to crack: Developmental patterns of drug involvement. American Journal of Public Health, 83(6): 851-855, 1993.

National Cancer Institute, Major Local Tobacco Control Ordinances in the United States, Monograph 3, Bethesda, Maryland: U.S. Department of Health and Human Services, Public Health Services, National Institutes of Health, 1993.

Pacula RL. Does increasing the beer tax reduce marijuana consumption? Journal of Health Economics 17(5):557-586, 1998a.

Pacula RL. Adolescent alcohol and marijuana use: Is there really a gateway effect? National Bureau of Economic Research Working Paper Number 6348, 1998b.

Saffer H, Chaloupka FJ. Demographic differentials in the demand for alcohol and illicit drugs. National Bureau of Economic Research Working Paper Number 6432, 1998.

Tobacco Institute, The Tax Burden on Tobacco, Washington D.C.: Tobacco Institute, 1995.

U.S. Brewers Association. Brewers Almanac. Washington, D.C.: U.S. Brewers Association, 1997.

US Department of Health and Human Services. Preventing Tobacco Use Among Young People. A Report of the Surgeon General. US Department of Health and Human Services, Public Health Service, Centers for Disease Control, Center for Health Promotion and Education, Office on Smoking and Health. DHHS Publication No. (CDC) 95-0110, 1994.

US Department of Health and Human Services. The Health Consequences of Smoking: Nicotine Addiction. A Report of the Surgeon General. US Department of Health and Human Services, Public Health Service, Centers for Disease Control, Center for Health Promotion and Education, Office on Smoking and Health. DHHS Publication No. (CDC) 88-8406, 1988. 
Table 1

Current Cigarette and Marijuana Users

MTF 1992-1994 (Unweighted)

\begin{tabular}{|c|c|c|c|}
\hline $\begin{array}{l}\text { Frequency } \\
\text { Percent } \\
\text { Row Percent } \\
\text { Column Percent }\end{array}$ & $\begin{array}{c}\text { Current cigarette } \\
\text { user } \\
\text { NO }\end{array}$ & $\begin{array}{c}\text { Current cigarette } \\
\text { user } \\
\text { YES }\end{array}$ & Total \\
\hline $\begin{array}{c}\text { Current Marijuana } \\
\text { user } \\
\text { NO } \\
\end{array}$ & $\begin{array}{c}81,228 \\
74.11 \% \\
83.21 \% \\
95.90 \%\end{array}$ & $\begin{array}{c}16,388 \\
14.95 \% \\
16.79 \% \\
65.79 \%\end{array}$ & $\begin{array}{c}97,616 \\
89.06 \%\end{array}$ \\
\hline $\begin{array}{c}\text { Current Marijuana } \\
\text { user } \\
\text { YES } \\
\end{array}$ & $\begin{array}{c}3475 \\
3.17 \% \\
28.97 \% \\
4.10 \%\end{array}$ & $\begin{array}{c}8521 \\
7.77 \% \\
71.03 \% \\
34.21 \%\end{array}$ & $\begin{array}{c}11,996 \\
10.94 \%\end{array}$ \\
\hline Total & $\begin{array}{c}84,703 \\
77.28 \%\end{array}$ & $\begin{array}{c}24,909 \\
22.72 \%\end{array}$ & $\begin{array}{c}109,612 \\
100 \%\end{array}$ \\
\hline
\end{tabular}


Table Two

Descriptive Statistics $^{\mathrm{a}}$

\begin{tabular}{|c|c|c|}
\hline Variable & Mean & $\begin{array}{l}\text { Standard } \\
\text { Deviation }\end{array}$ \\
\hline Current Cigarette Smoking & 0.227 & 0.419 \\
\hline Average Daily Cigarette Consumption & 5.623 & 8.170 \\
\hline Natural Log of Average Daily Cigarette Consumption & 0.740 & 1.440 \\
\hline Current Marijuana Use & 0.109 & 0.312 \\
\hline Frequency of Marijuana Use, Past 30 Days & 9.066 & 12.466 \\
\hline Natural Log of Marijuana Use Frequency & 1.506 & 1.129 \\
\hline Real Cigarette Price & 124.749 & 13.563 \\
\hline Border Price Difference & 4.437 & 7.594 \\
\hline Smoking Restriction Index & 3.754 & 1.442 \\
\hline Youth Access Index & 3.972 & 0.980 \\
\hline Earmarked Tobacco Tax & 0.158 & 0.365 \\
\hline Smoker Protection Law & 0.477 & 0.499 \\
\hline Marijuana Decriminalization & 0.294 & 0.456 \\
\hline Median Fine for Marijuana Possession & 7689.16 & 35317.17 \\
\hline Median Jail Term for Marijuana Possession & 1.257 & 1.779 \\
\hline Marijuana Penalties for 1994 Only Indicator & 0.102 & 0.303 \\
\hline Real Beer Tax & 0.004 & 0.004 \\
\hline Male & 0.479 & 0.500 \\
\hline African-American & 0.115 & 0.319 \\
\hline Other Race & 0.208 & 0.406 \\
\hline Age & 16.095 & 1.821 \\
\hline Eighth or Tenth Grade & 0.690 & 0.462 \\
\hline Average Hours Worked & 7.001 & 9.618 \\
\hline Real Weekly Income & 31.383 & 34.987 \\
\hline Infrequent Attendance at Religious Services & 0.485 & 0.500 \\
\hline Frequent Attendance at Religious Services & 0.384 & 0.486 \\
\hline Rural & 0.270 & 0.444 \\
\hline Live Alone & 0.004 & 0.060 \\
\hline Live with Father Only & 0.033 & 0.180 \\
\hline Live with Mother Only & 0.154 & 0.361 \\
\hline Other Family Structure & 0.029 & 0.168 \\
\hline Siblings Present & 0.764 & 0.425 \\
\hline Father less than High School Education & 0.134 & 0.341 \\
\hline Father more than High School Education & 0.577 & 0.494 \\
\hline Mother less than High School Education & 0.122 & 0.327 \\
\hline Mother more than High School Education & 0.552 & 0.497 \\
\hline Married or Engaged & 0.023 & 0.150 \\
\hline Mother Worked Part Time & 0.218 & 0.413 \\
\hline Mother Worked Full Time & 0.578 & 0.494 \\
\hline 1992 & 0.325 & 0.469 \\
\hline 1993 & 0.339 & 0.473 \\
\hline West & 0.191 & 0.393 \\
\hline Midwest & 0.300 & 0.458 \\
\hline Northeast & 0.373 & 0.483 \\
\hline
\end{tabular}

Sample size 109,612. 
Table Three

Probabilities of Cigarette Smoking and Marijuana Use, Marginal Effects ${ }^{a}$

\begin{tabular}{|c|c|c|c|c|}
\hline Independent Variable & $\begin{array}{c}\text { Probability } \\
\text { of Cigarette } \\
\text { Smoking }\end{array}$ & $\begin{array}{c}\text { Probability } \\
\text { of Cigarette } \\
\text { Smoking }\end{array}$ & $\begin{array}{c}\text { Probability } \\
\text { of Marijuana } \\
\text { Use }\end{array}$ & $\begin{array}{c}\text { Probability of } \\
\text { Marijuana } \\
\text { Use }\end{array}$ \\
\hline Real Cigarette Price & $\begin{array}{l}-0.0011 \\
(-4.76)\end{array}$ & $\begin{array}{l}-0.0007 \\
(-2.06)\end{array}$ & $\begin{array}{l}-0.0002 \\
(-1.36)\end{array}$ & $\begin{array}{r}-0.0005 \\
(-1.76)\end{array}$ \\
\hline Border Price Difference & 0.0002 & 0.0003 & 0.0003 & 0.0003 \\
\hline & $(0.67)$ & $(0.97)$ & $(1.54)$ & $(1.48)$ \\
\hline Smoking Restriction Index & & $\begin{array}{r}-0.0050 \\
(-1.70)\end{array}$ & & $\begin{array}{l}0.0025 \\
(1.02)\end{array}$ \\
\hline Youth Access Index & & $\begin{array}{l}-0.0019 \\
(-060)\end{array}$ & & -0.0003 \\
\hline Earmarked Tobacco Tax & & $\begin{array}{r}-0.0082 \\
(-0.84)\end{array}$ & & $\begin{array}{r}-0.0007 \\
(-0.13)\end{array}$ \\
\hline Smoker Protection Law & & $\begin{array}{c}-0.0038 \\
(-0.63)\end{array}$ & & $\begin{array}{r}-0.0039 \\
(-0.75)\end{array}$ \\
\hline Marijuana Decriminalization & $\begin{array}{l}0.0015 \\
(0.24)\end{array}$ & $\begin{array}{l}0.0044 \\
(0.60)\end{array}$ & $\begin{array}{l}0.0093 \\
(1.72)\end{array}$ & $\begin{array}{l}0.0136 \\
(2.25)\end{array}$ \\
\hline $\begin{array}{l}\text { Median Fine for Marijuana } \\
\text { Possession }\end{array}$ & & $\begin{array}{c}-8.98 \mathrm{E}-08 \\
(-1.52)\end{array}$ & & $\begin{array}{c}-3.37 \mathrm{E}-08 \\
(-1.03)\end{array}$ \\
\hline $\begin{array}{l}\text { Median Jail Term for } \\
\text { Marijuana Possession }\end{array}$ & & $\begin{array}{c}0.0018 \\
(1.07)\end{array}$ & & $\begin{array}{r}-0.0013 \\
(-1.00)\end{array}$ \\
\hline $\begin{array}{l}\text { Marijuana Penalties for } 1994 \\
\text { Only Indicator }\end{array}$ & & $\begin{array}{r}-0.0094 \\
(-1.39)\end{array}$ & & $\begin{array}{r}-0.0131 \\
(-2.31)\end{array}$ \\
\hline Real Beer Tax & $\begin{array}{c}-0.2479 \\
(-0.35)\end{array}$ & $\begin{array}{l}-1.296 \\
(-1.56)\end{array}$ & $\begin{array}{r}-0.1221 \\
(-0.14)\end{array}$ & $\begin{array}{l}0.1584 \\
(0.22)\end{array}$ \\
\hline Male & $\begin{array}{c}-0.0136 \\
(-2.70)\end{array}$ & $\begin{array}{r}-0.0135 \\
(-2.69)\end{array}$ & $\begin{array}{l}0.0236 \\
(8.92)\end{array}$ & $\begin{array}{l}0.0238 \\
(9.03)\end{array}$ \\
\hline African-American & $\begin{array}{l}-0.1807 \\
(-26.68)\end{array}$ & $\begin{array}{l}-0.1802 \\
(-26.03)\end{array}$ & $\begin{array}{c}-0.0450 \\
(-6.59)\end{array}$ & $\begin{array}{r}-0.0446 \\
(-6.63)\end{array}$ \\
\hline Other Race & $\begin{array}{c}-0.0292 \\
(-6.84)\end{array}$ & $\begin{array}{r}-0.0285 \\
(-6.90)\end{array}$ & $\begin{array}{r}-0.0044 \\
(-0.94)\end{array}$ & $\begin{array}{r}-0.0048 \\
(-1.03)\end{array}$ \\
\hline Age & $\begin{array}{l}0.1482 \\
(6.93)\end{array}$ & $\begin{array}{l}0.1487 \\
(6.88)\end{array}$ & $\begin{array}{l}0.1636 \\
(9.02)\end{array}$ & $\begin{array}{l}0.1654 \\
(9.36)\end{array}$ \\
\hline Age Squared & $\begin{array}{l}-0.0040 \\
(-6.35)\end{array}$ & $\begin{array}{r}-0.0041 \\
(-6.33)\end{array}$ & $\begin{array}{r}-0.0045 \\
(-8.32)\end{array}$ & $\begin{array}{r}-0.0046 \\
(-8.64)\end{array}$ \\
\hline Eighth or Tenth Grade & $\begin{array}{c}0.0114 \\
(1.51)\end{array}$ & $\begin{array}{c}0.0117 \\
(1.55)\end{array}$ & $\begin{array}{c}-0.0049 \\
(-1.06)\end{array}$ & $\begin{array}{c}-0.0042 \\
(-0.89)\end{array}$ \\
\hline Average Hours Worked & $\begin{array}{l}0.0010 \\
(5.43)\end{array}$ & $\begin{array}{l}0.0010 \\
(5.44)\end{array}$ & $\begin{array}{r}-0.0003 \\
(-2.30)\end{array}$ & $\begin{array}{r}-0.0003 \\
(-2.37)\end{array}$ \\
\hline Real Weekly Income & $\begin{array}{l}0.0022 \\
(16.81)\end{array}$ & $\begin{array}{l}0.0021 \\
(16.86)\end{array}$ & $\begin{array}{l}0.0012 \\
(14.06)\end{array}$ & $\begin{array}{l}0.0011 \\
(14.09)\end{array}$ \\
\hline Income Squared & $\begin{array}{c}-7.96 \mathrm{E}-06 \\
(-10.57)\end{array}$ & $\begin{array}{c}-7.94 \mathrm{E}-06 \\
(-10.60)\end{array}$ & $\begin{array}{c}-3.72 \mathrm{E}-06 \\
(-7.40)\end{array}$ & $\begin{array}{c}-3.71 \mathrm{E}-06 \\
(-7.39)\end{array}$ \\
\hline
\end{tabular}




\begin{tabular}{|c|c|c|c|c|}
\hline Independent Variable & $\begin{array}{c}\text { Probability } \\
\text { of Cigarette } \\
\text { Smoking } \\
\end{array}$ & $\begin{array}{c}\text { Probability } \\
\text { of Cigarette } \\
\text { Smoking } \\
\end{array}$ & $\begin{array}{c}\text { Probability } \\
\text { of Marijuana } \\
\text { Use } \\
\end{array}$ & $\begin{array}{c}\text { Probability of } \\
\text { Marijuana } \\
\text { Use } \\
\end{array}$ \\
\hline Infrequent Attendance at & -0.0468 & -0.0468 & -0.0400 & -0.0397 \\
\hline Religious Services & $(-11.88)$ & $(-11.90)$ & $(-12.77)$ & $(-13.09)$ \\
\hline Frequent Attendance at & -0.1320 & -0.1322 & -0.0952 & -0.0949 \\
\hline Religious Services & $(-24.07)$ & $(-24.18)$ & $(-28.41)$ & $(-28.85)$ \\
\hline \multirow[t]{2}{*}{ Rural } & -0.0057 & -0.0065 & -0.0237 & -0.0227 \\
\hline & $(-1.05)$ & $(-1.25)$ & $(-6.73)$ & $(-6.59)$ \\
\hline \multirow[t]{2}{*}{ Live Alone } & 0.1337 & 0.1343 & 0.0676 & 0.0670 \\
\hline & $(5.80)$ & $(5.80)$ & $(5.23)$ & $(5.16)$ \\
\hline \multirow[t]{2}{*}{ Live with Father Only } & 0.0658 & 0.0659 & 0.0330 & 0.0327 \\
\hline & $(9.25)$ & $(9.26)$ & $(6.78)$ & $(6.81)$ \\
\hline \multirow[t]{2}{*}{ Live with Mother Only } & 0.0361 & 0.0362 & 0.0276 & 0.0275 \\
\hline & $(7.03)$ & $(7.08)$ & $(10.46)$ & $(10.41)$ \\
\hline \multirow[t]{2}{*}{ Other Family Structure } & 0.0597 & 0.0597 & 0.0406 & 0.0405 \\
\hline & $(6.17)$ & $(6.18)$ & $(10.77)$ & $(10.80)$ \\
\hline \multirow[t]{2}{*}{ Siblings Present } & -0.0206 & -0.0205 & -0.0144 & -0.0143 \\
\hline & $(-5.28)$ & $(-5.30)$ & $(-6.75)$ & $(-6.65)$ \\
\hline Father Less Than High & 0.0215 & 0.0215 & 0.0126 & 0.0126 \\
\hline School Education & $(3.61)$ & $(3.61)$ & $(2.93)$ & $(2.93)$ \\
\hline Father More Than High & -0.0080 & -0.0078 & 0.0035 & 0.0035 \\
\hline School Education & $(-2.30)$ & $(-2.28)$ & $(1.36)$ & $(1.34)$ \\
\hline Mother Less Than High & 0.0160 & 0.0161 & 0.0063 & 0.0064 \\
\hline School Education & $(2.31)$ & $(2.32)$ & $(1.61)$ & $(1.66)$ \\
\hline Mother More Than High & -0.0066 & -0.0064 & 0.0031 & 0.0031 \\
\hline School Education & $(-1.79)$ & $(-1.72)$ & $(1.48)$ & $(1.46)$ \\
\hline \multirow[t]{2}{*}{ Married or Engaged } & 0.0256 & 0.0255 & -0.0206 & -0.0205 \\
\hline & $(2.96)$ & $(2.99)$ & $(-3.70)$ & $(-3.65)$ \\
\hline \multirow[t]{2}{*}{ Mother Worked Part Time } & 0.0074 & 0.0073 & 0.0016 & 0.0015 \\
\hline & $(2.20)$ & $(2.17)$ & $(0.65)$ & $(0.61)$ \\
\hline \multirow[t]{2}{*}{ Mother Worked Full Time } & 0.0144 & 0.0144 & 0.0061 & 0.0060 \\
\hline & $(5.54)$ & $(5.47)$ & $(3.02)$ & $(2.95)$ \\
\hline \multirow[t]{2}{*}{1992} & -0.0028 & -0.0086 & -0.0357 & -0.0312 \\
\hline & $(-0.51)$ & $(-1.26)$ & $(-9.76)$ & $(-6.73)$ \\
\hline \multirow[t]{2}{*}{1993} & -0.0065 & -0.0096 & -0.0279 & -0.0234 \\
\hline & $(-1.29)$ & $(-1.51)$ & $(-11.04)$ & $(-7.89)$ \\
\hline \multirow[t]{2}{*}{ West } & -0.0506 & -0.0430 & 0.0183 & 0.0132 \\
\hline & $(-5.67)$ & $(-3.71)$ & $(2.87)$ & $(2.05)$ \\
\hline \multirow[t]{2}{*}{ Midwest } & -0.0024 & 0.0068 & 0.0088 & 0.0053 \\
\hline & $(-0.35)$ & $(0.77)$ & $(1.57)$ & $(0.73)$ \\
\hline \multirow[t]{2}{*}{ Northeast } & -0.0076 & 0.0025 & 0.0060 & 0.0055 \\
\hline & $(-1.18)$ & $(0.27)$ & $(1.20)$ & $(0.87)$ \\
\hline
\end{tabular}

${ }^{\mathrm{a}}$ Asymptotic t-ratios are in the parentheses. Marginal effects for dichotomous indicators reflect a change in the independent variable from 0 to 1 . The critical value for the t-ratios are 2.58 (2.33), 1.96 (1.64), and 1.64 (1.28) at the one, five, and ten percent significance levels respectively, based on a two-tailed (one-tailed) test. All equations also include a constant. 
Table Four

Conditional Cigarette Demand and Marijuana Use ${ }^{\text {a }}$

\begin{tabular}{|c|c|c|c|c|}
\hline Independent Variable & $\begin{array}{c}\text { Frequency } \\
\text { of Cigarette } \\
\text { Smoking }\end{array}$ & $\begin{array}{l}\text { Frequency of } \\
\text { Cigarette } \\
\text { Smoking }\end{array}$ & $\begin{array}{c}\text { Frequency of } \\
\text { Marijuana } \\
\text { Use }\end{array}$ & $\begin{array}{c}\text { Frequency of } \\
\text { Marijuana } \\
\text { Use }\end{array}$ \\
\hline Real Cigarette Price & $\begin{array}{l}-0.0050 \\
(-3.45)\end{array}$ & $\begin{array}{l}-0.0057 \\
(-3.17)\end{array}$ & $\begin{array}{c}-0.0029 \\
(-2.02)\end{array}$ & $\begin{array}{r}-0.0067 \\
(-4.06)\end{array}$ \\
\hline Border Price Difference & $\begin{array}{l}0.0029 \\
(1.68)\end{array}$ & $\begin{array}{l}0.0027 \\
(1.61)\end{array}$ & $\begin{array}{l}0.0029 \\
(1.84)\end{array}$ & $\begin{array}{l}0.0030 \\
(2.03)\end{array}$ \\
\hline Smoking Restriction Index & & $\begin{array}{l}0.0060 \\
(0.38)\end{array}$ & & $\begin{array}{l}0.0512 \\
(3.15)\end{array}$ \\
\hline Youth Access Index & & $\begin{array}{l}0.0164 \\
(1.29)\end{array}$ & & $\begin{array}{l}0.0020 \\
(0.122)\end{array}$ \\
\hline Earmarked Tobacco Tax & & $\begin{array}{l}0.0268 \\
(0.54)\end{array}$ & & $\begin{array}{l}0.0200 \\
(0.43)\end{array}$ \\
\hline Smoker Protection Law & & $\begin{array}{l}0.0207 \\
(0.65)\end{array}$ & & $\begin{array}{r}-0.0258 \\
(-0.78)\end{array}$ \\
\hline Marijuana Decriminalization & $\begin{array}{c}-0.0061 \\
(-0.18)\end{array}$ & $\begin{array}{l}0.0021 \\
(0.063)\end{array}$ & $\begin{array}{c}0.0204 \\
(0.50)\end{array}$ & $\begin{array}{l}0.0597 \\
(2.07)\end{array}$ \\
\hline $\begin{array}{l}\text { Median Fine for Marijuana } \\
\text { Possession }\end{array}$ & & $\begin{array}{l}-4.75 \mathrm{E}-08 \\
(-0.14)\end{array}$ & & $\begin{array}{c}-6.68 \mathrm{E}-07 \\
(-2.38)\end{array}$ \\
\hline $\begin{array}{l}\text { Median Jail Term for } \\
\text { Marijuana Possession }\end{array}$ & & $\begin{array}{l}0.0053 \\
(0.51)\end{array}$ & & $\begin{array}{r}-0.0022 \\
(-0.35)\end{array}$ \\
\hline $\begin{array}{l}\text { Marijuana Penalties for } 1994 \\
\text { Only Indicator }\end{array}$ & & $\begin{array}{c}-0.0412 \\
(-0.86)\end{array}$ & & $\begin{array}{r}-0.1124 \\
(-2.88)\end{array}$ \\
\hline Real Beer Tax & $\begin{array}{l}-3.722 \\
(-1.46)\end{array}$ & $\begin{array}{l}-3.1516 \\
(-0.75)\end{array}$ & $\begin{array}{l}2.8145 \\
(0.46)\end{array}$ & $\begin{array}{l}6.6256 \\
(1.87)\end{array}$ \\
\hline Male & $\begin{array}{l}0.0441 \\
(1.94)\end{array}$ & $\begin{array}{l}0.0431 \\
(1.92)\end{array}$ & $\begin{array}{l}0.2172 \\
(10.18)\end{array}$ & $\begin{array}{l}0.2198 \\
(10.44)\end{array}$ \\
\hline African-American & $\begin{array}{l}-0.7169 \\
(-11.60)\end{array}$ & $\begin{array}{l}-0.7178 \\
(-11.47)\end{array}$ & $\begin{array}{c}-0.2834 \\
(-5.79)\end{array}$ & $\begin{array}{r}-0.2767 \\
(-5.73)\end{array}$ \\
\hline Other Race & $\begin{array}{r}-0.1300 \\
(-3.26)\end{array}$ & $\begin{array}{r}-0.1300 \\
(-3.29)\end{array}$ & $\begin{array}{l}0.0046 \\
(0.17)\end{array}$ & $\begin{array}{r}-0.0068 \\
(-0.26)\end{array}$ \\
\hline Age & $\begin{array}{l}0.5366 \\
(3.51)\end{array}$ & $\begin{array}{l}0.5350 \\
(3.57)\end{array}$ & $\begin{array}{l}0.1954 \\
(1.33)\end{array}$ & $\begin{array}{l}0.2308 \\
(1.63)\end{array}$ \\
\hline Age Squared & $\begin{array}{c}-0.0130 \\
(-2.64)\end{array}$ & $\begin{array}{r}-0.0130 \\
(-2.68)\end{array}$ & $\begin{array}{c}-0.0038 \\
(-0.81)\end{array}$ & $\begin{array}{r}-0.0048 \\
(-1.07)\end{array}$ \\
\hline Eighth or Tenth Grade & $\begin{array}{l}0.1598 \\
(3.86)\end{array}$ & $\begin{array}{l}0.1602 \\
(3.77)\end{array}$ & $\begin{array}{c}-0.0486 \\
(-1.33)\end{array}$ & $\begin{array}{r}-0.0441 \\
(-1.14)\end{array}$ \\
\hline Average Hours Worked & $\begin{array}{l}0.0075 \\
(5.55)\end{array}$ & $\begin{array}{l}0.0075 \\
(5.50)\end{array}$ & $\begin{array}{r}-0.0017 \\
(-1.23)\end{array}$ & $\begin{array}{r}-0.0018 \\
(-1.33)\end{array}$ \\
\hline Real Weekly Income & $\begin{array}{l}0.0025 \\
(6.00)\end{array}$ & $\begin{array}{l}0.0025 \\
(5.91)\end{array}$ & $\begin{array}{l}0.0020 \\
(2.26)\end{array}$ & $\begin{array}{l}0.0020 \\
(2.26)\end{array}$ \\
\hline Income Squared & $\begin{array}{c}\text { 7.97E-06 } \\
(2.95)\end{array}$ & $\begin{array}{c}7.98 \mathrm{E}-06 \\
(2.94)\end{array}$ & $\begin{array}{c}6.39 \mathrm{E}-06 \\
(1.34)\end{array}$ & $\begin{array}{c}6.52 \mathrm{E}-06 \\
(1.37)\end{array}$ \\
\hline
\end{tabular}




\begin{tabular}{|c|c|c|c|c|}
\hline Independent Variable & $\begin{array}{c}\text { Frequency } \\
\text { of Cigarette } \\
\text { Smoking }\end{array}$ & $\begin{array}{c}\text { Frequency of } \\
\text { Cigarette } \\
\text { Smoking }\end{array}$ & $\begin{array}{c}\text { Frequency of } \\
\text { Marijuana } \\
\text { Use }\end{array}$ & $\begin{array}{c}\text { Frequency of } \\
\text { Marijuana } \\
\text { Use }\end{array}$ \\
\hline Infrequent Attendance at & -0.3928 & -0.3934 & -0.2404 & -0.2396 \\
\hline Religious Services & $(-17.27)$ & $(-17.42)$ & $(-9.42)$ & $(-9.53)$ \\
\hline Frequent Attendance at & -0.6400 & -0.6414 & -0.3884 & -0.3871 \\
\hline Religious Services & $(-29.10)$ & $(-28.43)$ & $(-13.08)$ & $(-13.41)$ \\
\hline \multirow[t]{2}{*}{ Rural } & -0.0540 & -0.0550 & -0.0426 & -0.0243 \\
\hline & $(-2.31)$ & $(-2.38)$ & $(-1.42)$ & $(-0.81)$ \\
\hline \multirow[t]{2}{*}{ Live Alone } & 0.6427 & 0.6422 & 0.2587 & 0.2540 \\
\hline & $(5.53)$ & $(5.53)$ & $(1.95)$ & $(1.93)$ \\
\hline Live with Father Only & 0.2199 & 0.2199 & 0.1162 & 0.1153 \\
\hline Live with Mother Only & $\begin{array}{l}0.1577 \\
(5.35)\end{array}$ & $\begin{array}{c}0.1574 \\
(5.38)\end{array}$ & $\begin{array}{c}0.0376 \\
(1.24)\end{array}$ & $\begin{array}{l}0.0355 \\
(1.20)\end{array}$ \\
\hline Other Family Structure & $\begin{array}{c}0.3337 \\
(5.83)\end{array}$ & $\begin{array}{c}0.3329 \\
(5.85)\end{array}$ & $\begin{array}{c}0.0833 \\
(1.89)\end{array}$ & $\begin{array}{c}0.0884 \\
(2.01)\end{array}$ \\
\hline Siblings Present & $\begin{array}{c}-0.0697 \\
(-3.18)\end{array}$ & $\begin{array}{c}-0.0704 \\
(-3.18)\end{array}$ & $\begin{array}{c}-0.0466 \\
(-2.10)\end{array}$ & $\begin{array}{c}-0.0473 \\
(-2.15)\end{array}$ \\
\hline $\begin{array}{l}\text { Father Less Than High } \\
\text { School Education }\end{array}$ & $\begin{array}{c}0.1150 \\
(3.01)\end{array}$ & $\begin{array}{l}0.1151 \\
(2.97)\end{array}$ & $\begin{array}{r}0.0732 \\
(2.31)\end{array}$ & $\begin{array}{l}0.0712 \\
(2.25)\end{array}$ \\
\hline Father More Than High & -0.1118 & -0.1123 & 0.0113 & 0.0079 \\
\hline School Education & $(-6.03)$ & $(-5.99)$ & $(0.50)$ & $(0.36)$ \\
\hline Mother Less Than High & 0.0496 & 0.0504 & 0.0069 & 0.011 \\
\hline School Education & $(1.21)$ & $(1.22)$ & $(0.16)$ & $(0.23)$ \\
\hline Mother More Than High & -0.0754 & -0.0754 & -0.0078 & -0.0096 \\
\hline School Education & $(-4.18)$ & $(-4.16)$ & $(-0.37)$ & $(-0.44)$ \\
\hline \multirow[t]{2}{*}{ Married or Engaged } & 0.4009 & 0.4019 & 0.1567 & 0.1611 \\
\hline & $(10.76)$ & $(10.77)$ & $(2.62)$ & $(2.72)$ \\
\hline \multirow[t]{2}{*}{ Mother Worked Part Time } & -0.0514 & -0.0521 & -0.0337 & -0.0359 \\
\hline & $(-1.99)$ & $(-1.99)$ & $(-1.21)$ & $(-1.29)$ \\
\hline \multirow[t]{2}{*}{ Mother Worked Full Time } & 0.0336 & 0.0326 & 0.0051 & 0.0035 \\
\hline & $(1.15)$ & $(1.10)$ & $(0.19)$ & $(0.13)$ \\
\hline \multirow[t]{2}{*}{1992} & 0.1115 & 0.1373 & -0.1384 & -0.0694 \\
\hline & $(3.29)$ & $(3.33)$ & $(-4.28)$ & $(-2.08)$ \\
\hline \multirow[t]{2}{*}{1993} & 0.0691 & 0.0887 & -0.0913 & -0.0327 \\
\hline & $(2.50)$ & $(2.56)$ & $(-3.05)$ & $(-1.04)$ \\
\hline \multirow[t]{2}{*}{ West } & -0.1996 & -0.2329 & 0.1389 & 0.0348 \\
\hline & $(-2.34)$ & $(-2.42)$ & $(2.76)$ & $(0.66)$ \\
\hline \multirow[t]{2}{*}{ Midwest } & -0.0085 & -0.0274 & 0.0699 & -0.0082 \\
\hline & $(-0.13)$ & $(-0.37)$ & (1.64) & $(-0.22)$ \\
\hline \multirow[t]{2}{*}{ Northeast } & 0.0725 & 0.0629 & 0.0658 & 0.0065 \\
\hline & (1.09) & $(0.89)$ & (2.03) & $(0.16)$ \\
\hline
\end{tabular}

${ }^{a}$ t-ratios are in the parentheses. The critical value for the t-ratios are 2.58 (2.33), $1.96(1.64)$, and 1.64 (1.28) at the one, five, and ten percent significance levels respectively, based on a two-tailed (one-tailed) test. All equations, based on an F test, are significant at the one-percent level. All equations also include a constant. 